\title{
The l/eye is in the verb: Towards a poetics of the feminist poetic $I$
}

\author{
Hanna Hallgren
}

For several years, I have committed myself to artistic research; a commitment both as a poet and as a scholar in Gender Studies. In this article I start to raise questions about the status of the "I" in feminist academic texts - and the idea of the "I" as a sign pointing towards situatedness and accountability. I do this through experiences of writing in an "I" form, using the pronoun "I", in poetry and fiction writing. The method used is writing as a method of nomadic inquiry (Richardson \& Adams St. Pierre 2005). This is a method in which one tries to shape one's thinking through writing, instead of reporting what one has thought already. Regarding the article's theoretical inspiration, I would declare poetry and feminist philosophy as the main sources. This means that I consider both poetry/fiction writing and philosophy to be fruitful spheres for knowledge production. The aim of the article is to ask questions about the "I", in ways trying to evoke some of the feminist complexity attached to this pronoun.

\section{Chapter $I^{1}$}

I will take into account ... myself. Or, as Monique Wittig puts it, the italic I or divided J/e will - since the "I" is always already occupied and marked by family fathers walking straight ahead on the pavement to their cars and their dreams and long-lasting histories, and memories of other fathers walking to their cars, carrying names that smelled of Jasmine and cigars (Wittig 1969). Blossoming men, full of language-organs, and voices of choirs in their heads: fathers singing themselves, fathers hearing themselves. A father carrying a father in his palm; as a promise, a stone's breath, a word and a world almost encompassed in his hand. Or some of the fathers, since they - too - are divided into I's and I's, and divided in themselves, as slices of flesh and abysses of holes, while they live to be able to give everything up, to give up, they too shall give up, and sleep without words. Some of the fathers might even incurporate a corps lesbien, a lesbian body. We can't be sure, since the I/eye is in the verb, and the fathers might change, become trees, and as trees become silhouettes in themselves, as did my father when he lost his speech, and his eyes came closer to me than before; blue ink bolts scribbling for life, and $I$ wrote with my hands over his face: this too shall pass.

\footnotetext{
${ }^{1}$ To call each chapter "Chapter $I$ " is an idea I got from the poet Jenny Tunedal and her poetry book Kapitel Ett (Chapter One) (2008).
} 


\section{Chapter 1}

What embraces one's shadow here?

Ingeborg Bachmann

The light of the room is half

But the shadow lives as a tree

Hanna Hallgren

My mother is alive, my father is gone, and $I$ will speak of the feminist poetic $I$. As flesh, remembrances, fluids and hopes. As a sign in a text, noun in a genre, and as a promise of performativity ... or rather: life. Yes, a promise of life: this is life, its wings and roots and Limonade es war alles so grenzenlos. ${ }^{2}$ I will tell lies and speak only the truth, and sometimes disappear, whirling away, go to sleep, suggest another story, replace myself with the story of my mother and kneel in front of the mercy seat. $I$ will ask you to forgive me, since $I$ can't count on myself, can't count myself, $I$ will try to be as reliable as possible, but nothing changes as often and as much as the past, and the future is not easy to remember. It comes whirling off. Everything is rapid, soon gone, like whistling bones, strong wind, buttons as tender as ashes, and in the morning, $I$ dreamed $I$ saw the face of a murderer: iconic and pale. $I$ pick the wild roses with a fork, as one gets plucked by a word and dragged into the world by one's name, just to be swept away by a most horrific and unreliable $I$. This is why $I$ started to pick nettles barehanded, and roses with forks. Since, how much more often a rose will not prick you, than a nettle burn? ${ }^{3}$ Marina Tsvetajeva states, the philosopher asks questions, the poet invents answers, and maybe it's like this. ${ }^{4}$ Maybe, under the snow, a world is born, if one believes: "Let there be for now / no feeling expressed, / let the heart's muscle / exercise in another way". 5 As waiting for longing, a life when time and years only cover duration, dura-ti-on, a covering word, a world where one dives into the sky or the sea not being able to tell the difference. Plankton as stars, and starfish tiny fingers written over the dark sky. The invention of a word-world, where one keeps falling and rising, weightless,

\section{Chapter $I$}

$I$ have dedicated myself to poetry, since life doesn't follow the logics of story-telling, like the word, life will only drag other lives behind it, the sentence a sentence, ${ }^{6}$ and by now $I$ know the dead are living amongst us: "The world in which the dead are living is a silent choir / It

\footnotetext{
${ }^{2}$ A quotation from Kafka which I found in Coming to Writing and Other Essays (1992), a book by Hélène Cixous.

${ }^{3}$ A quotation from the Swedish writer Selma Lagerlöf (1858-1940).

${ }^{4}$ See Marina Tsvetajeva I skuggan av ett krig (2011).

5 Ingeborg Bachmann, "You Words", Darkness Spoken (2006), pp. 335 f.

${ }^{6}$ Ibid.
} 
doesn't hear itself, it doesn't sing itself.,"7 If there is a difference between the worlds, a wordworld, clear as spit, it won't enlighten us about anything, since neither we, nor they, can hear their singing. But as far as $I$ know, they are here, never asking if they are allowed to pass the threshold of life. Never asked if they were allowed to leave. Like rude dinner guests, they come and go, a silent rudeness, not possible to grasp, and there is nothing we know of to pass.

\section{Chapter I}

$I$ do not know myself, and $I$ wouldn't write if $I$ knew what to write, as if there was a story to be told about the world, as if there were soldiers on their toy horses galloping: "I don't know where to turn / Where it matters most / Where life is / Difference is / cold calla lilies / And when the mirror still / Reflects a face / that lingers / skin lingers / blue / hours by the skin / breathe / Do difference / breathe." I can't tell you who or why I am, or why I still strive, in a world where some people say: "I don't know why I waste my time being alive." But $I$ think of forgetfulness as a method in life, as in the Arabic saying "A human becomes human since she forgets", and of writing as a method not only of inquiry, but writing as a strategy of forgetfulness as well. ${ }^{8}$ Remember to be able to forget. To write one's skin into the skin and its bites: "O shut / your eyes, shut them! / Press your mouth to the bite!" ${ }^{9}$ Forget to be able to remember the future, its horizon: a future perfect of footsteps under a blossoming sky. Is there a home in my hands?

\section{Chapter I}

Take me out or take me home tonight, there are places everywhere, but no place to be seated. Neither on my mother's tongue, nor in the speechless mouth of my father. I can't dandle on her tongue-swing or sit on his lip-lap, under the stars, in the darkness, and think of lollipops and merry go rounds, and when $I$ am situated, $I$ sink as Europe sinks, porous and pale, constantly shrinking into the rhetoric of fascism and eaten by words. Each morning $I$ wake up to eat and to normalize the world I can't change with or without words, since the words keep on changing, changing me, and my tongue is an umbilical cord connected to the white ink which used to spread like clouds from the factory chimneys, every day, when $I$ was a child in the cold war. Remember the heydays: "a perception not only of the pastness of the past, but of its presence." $" 10$ The bunkers, we visited them in school, never allowed to enter, they were small chapels of dogma, we ought to know their place, but never to trespass. To enter would have embodied beliefs in wars to come, and to remember the wars in which no one needed to take shelter. Or: we took shelter in the idea of having bunkers we never made use of. I took shelter in my mother's arms since she was an officer in the army of God, the blood and the fire were hers, and her bonnet was her crown, and no war has ever been cold. With her, I stepped into the fire, and we flew over the village, the villas, the factories and the house of my grandmother, where our relatives slowly disappeared from the tables and turned into ashes, and we

\footnotetext{
${ }^{7}$ See Laura Riding, The Life of the Dead: With Ten Illustrations by John Aldridge (1933).

8 See Laurel Richardson and Elisabeth Adams St. Pierre, Writing: A Method of Inquiry, Handbook of Qualitative Research (2005), pp. 959-978.

${ }^{9}$ Bachmann, "The Native Land", pp. $180 \mathrm{f}$.

${ }^{10}$ Ibid, xxiii (a quotation from T. S. Eliot).
} 
became fewer and fewer on every Christmas's blurred photos. Then we flew to the churchyard, to water, and see the tulips walk on their stalks to the tombstones. I love her so. Her face glowed and was turned towards God. To confess is to be in love, the inside of love. Under the uniform, $I$ felt her heart, on her back her wings, and in the Cold War we spread our gospel: Bibles to Poland, prayers to the Christians in the Soviet Union, clothes and toys to the orphanage children in Romania. We signed a petition against the film The Last Temptation of Christ, since no fire has burned clearer. We were never cold, always in the fire, never in or at peace, struggling to set the whole world on fire: blue flames, pure blue, as the breaths of the Holy Ghost. We were fire and blood.

\section{Chapter $I$}

To water the soil, "water knows how to speak, a wave takes a wave by the hand", ${ }^{11}$ and $I$ was a child, ink of the past, can't write, ink of today, won't last, and the future will only press its own cause; signify victories, as stones of remembrance, under which the history will change and moulder like leaves, only remembered when crimes are to be legitimized as part of a nation without forgetfulness. The forgetfulness of leaves. Home is a place in a small Soviet. ${ }^{12}$ Neither countries, nor hands, will last. In the U.S. Christa Wolf held her passport, but lost her land, as if there were no there there, as if $I$ still could see it in her hand. As if the Trabants still drove across the streets in the DDR, and Hertha Müller swept the handkerchief around tears running from the Romanian bread. ${ }^{13}$ As if nothing has changed, there might be a tense for what once was, and still is encapsulated as a bite. Fresh teeth through the stone's veins. Streets and sunshine and stores, inhabitants, dogs and market places - all made of stone, there might be a place for this too. Some waves, somewhere. Or: imagine no one could tell you where you have been, or which place you are going to. Imagine this might be the circumstance for us all, that the time has been separated from the place. We can remember and forget, never return, and never know if we are able to keep the words fresh. Is there a home in my voice? Where is my finger's home? I put it in my mother's mouth. I put it in my own wounds. I place it under the iron curtain, and try to remember the rhymes of the atomic bomb in my poetry writing as a child. The cloud. The bodies of children my own age eaten by white flour. Their faces. Like a girl. Knowing they were dead, not knowing who they were. Like they belonged to the bomb, lost in history decades ago. I understood their lives were worth less than mine, people would tell me the opposite, but act as if my life was more precious, and $I$ knew from then on: one must not only unlearn one's privilege as one's loss, to not become crazy, one must also learn how to fantasize one's privilege as one's privilege. ${ }^{14}$ One must start measuring a fantasmatic distance. Literally: from one heart to another. It became the thickness and whiteness of my skin. This is why $I$ know $I$ write despite my ink covering other bodies as a white river, as flour and snow.

\footnotetext{
${ }^{11}$ Ibid, p. 163.

${ }^{12}$ A sentence from the Norwegian poet Tone Hødneø, translated by me into English.

13 Bachmann, "In Wartime", p. 245. The "handkerchief" is an item which Hertha Müller writes about, for example in her speech when she received the Nobel Prize.

14 The idea of "unlearning one's privilege as one's loss" stems from Gayati Chakravorty Spivak.
} 


\section{Chapter I}

What is there to confess? Kneeling in front of the mercy seat, trying to stay in place, to be able to tell things right. Once upon a time there was a green-eyed girl. She swallowed her story, though she tried to speak as freely as she could, since she did not know how to tell it, and because her belly was her shrine. She only knew she was far away, and present only through her absence, and to confess I don't know who I am or where I am, would simply not be enough: too much, and not enough. Why should $I$ confess? To stay in place, or to create a space? Like the invention of time - she invented a space/time, a word-world, in which poetry could lift the belly to the stars, and her feet walk upon water. ${ }^{15}$ Luminous plankton through the long and silent nights in the depths, black ink, drinking black, lifting her belly, and confess - $O$, wild nights / when I am with thee! ${ }^{16}$ There was never a father's law, but a mother's love, a passionate and whirling love without reason. When her mother went away, she used to say: I am the heart of my mother, and I am her lungs and her lips and eyes, and nothing will tear us apart. I have no father, and if I had he would be our son, lying in a small willow basket floating in the river. Or he would be a snake in paradise. She would never waste her life on him (a snake). She has me and God and everything. She never brought me to his altar, but dressed me with the Bible and swords. I was her knight, a crusader, who only wanted to do good, like fly my words into the past, and make it come out right. ${ }^{17}$ Or stick my swords into the present; to cut a future perfect, where the shore rhymes the horizon, and embers glow in its name. To always come back to her, and the specific moment when she stood on the stairs, and told her father she would leave him to become an officer in the army of love. She would leave him to sell the War Cry, to walk with Jesus through the slums, talking to drinkers at the pubs. The prayers as a thin crape covering her draining face. His face. Hers. His: "I can still see you, / what I am you cannot see / I am the parent /A child in my own arms / breathe and turn / Shadows into life."

\section{Chapter $I$}

There blinks an $I$ in my text, like a lighthouse of flesh. What have $I$ done? Committed myself ... made myself accountable... but to what? And to whom? Who am I talking about, and who's being situated? Why did $I$ drag this $I$ into my text and try to blend it with the other words? Bend it over. Do I know myself? Didn't $I$ tell you several times - I don't, and you probably don't. We could write a joint poem, and still be sure we haven't been able to tell things right, since it could always have been said differently. Through different words. And above all: why shall you trust me, when in fiction writing the "I" is probably the most unreliable of all pronouns, and in poetry the most unlimited: I-eyes-ice - I wish $I$ could tell you water like water, and bread as dough between my hands, but $I$ can't. $I$ wish there was a window glancing faces where history was made, and you would receive it as a poem. A bird pecking on the pane.

\footnotetext{
${ }^{15}$ See Gertrude Stein, Lifting Belly (2010).

${ }^{16}$ Emily Dickinson, see for example: http://www.poetryfoundation.org/poem/173343 (29 March 2016).

${ }^{17}$ Sentences influenced by Hélène Cixous' writing.
} 


\section{Chapter I}

I remember nothing, four walls and nothing, remember falling apart as a rain in November needles and needless to say, its nails stitches through the skin. Rain as rain covers. Remember grass when dew becomes frost under one's foot, and a girl asks "How long is that night, how hard is that darkness?" The rain as sleep, as a bringing. An upbringing in one's own arms, if that is possible, the closure of arms, as shields, and as a shelter when rain keeps falling. The night sustains its darkness. A fauna of leaves. At one point of weakness, you let your I play four walls, you let you, you let go. There is a swim, a late lake at night, where protection is moving one's limbs. Under the surface you ask for bread and time. Walking through water, its walls. Four walls, people forget how to breathe or say it's a matter of moving.

\section{References}

Bachmann, Ingeborg. 2006. Darkness Spoken: The Collected Poems. Brookline: Zephyr Press.

Cixous, Hélène. 1992. Coming to Writing. Coming to Writing and Other Essays. Cambridge: Harvard University Press.

Hallgren, Hanna. 2016. Det som övar annorlunda likt ett hjärta. Malmö: Pequod.

Richardson, Laurel \& Adams St. Pierre, Elisabeth. 2005. Writing: A Method of Inquiry. In Denzin, Norman \& Lincoln, Yvonna (eds.). The SAGE Handbook of Qualitative Research. London \& New Delhi: SAGE, pp. 959-978.

Riding, Laura. 1933. The Life of the Dead: With Ten Illustrations by John Aldridge. London: Arthur Barker.

Stein, Gertrude. 2010. Lifting Belly. Tallahassee: Naiad Press.

Tsvetajeva, Marina. 2011. I skuggan av ett krig. Lund: Ellerströms förlag.

Wittig, Monique. 1973. Le Corps lesbien. Paris: Les Éditions de Minuit. 